\title{
epiphany
}

Journal of the Faculty of Arts and Social Sciences

International University of Sarajevo

ISSN 1840-3719 / No. 4

Spring 2010

\section{Multiculturalism and Contemporary British Fiction: Londonstani and The Islamist}

\author{
Adriano Elia \\ University of Rome "Roma Tre"
}

In order to analyse all-encompassing issues such as 'Europe', 'black' and 'white', at the beginning of the $21^{\text {st }}$ century a reification of post-colonial and cultural studies theoretical tools is made possible by an ever-increasing permeability of the boundaries between subjects such as literature, sociology, contemporary history, political science, international relations, anthropology. By pursuing an interdisciplinary and pragmatic approach, one finds it difficult to identify a persuasive idea of 'Europe' when even its 'capital' Brussels has to face an identity compromise between Flemish and Walloons (AlSayyad, Castells 2002: p. 3); by the same token, it is hard to imagine that, say, Scottish people would define themselves first as Europeans, and then as British and Scottish - the opposite sequential order is much more likely. Traditional categories such as 'black' and 'white' are also being repeatedly challenged and disrupted, witness the recent publication of novels such as Gautam Malkani's Londonstani (2006) and Ed Husain's The Islamist (2007). The former displays a religion-free kind of identity describing the life of apolitical British-Asian teenage rude-boys; the latter, instead, is based on a real account of a British Muslim who, after becoming an Islamic fundamentalist, rejected political Islam and returned to normal life. Bearing in mind the diverse colonial histories and the dangers of historical revisionism, my essay aims to investigate the anti-essentialist condition of the 'black' British community, at times erroneously seen as a monolithic entity. ${ }^{1}$

\footnotetext{
${ }^{1}$ A noteworthy (and controversial) example of historical revisionism and counterfactual history is Niall Ferguson's book Empire: How Britain Made the Modern World (2004).
} 
Racial essentialism involves the attribution of a particular, fixed and immutable character to a group of people: in other words, it is a homogenising mental construction imbued with preconceptions and stereotypes. It is beyond the scope of this paper to contribute to the discussion around the complex and nuanced issue of racial essentialism. A lively debate on this notion was triggered, among others, by scholars such as Paul Gilroy and his critique of racial purism and absolutism; Salman Rushdie's idea of racial essentialism as the consequence of an old-fashioned exoticism that sees any ethnic community as a homogenous whole; or Gayatri Spivak's 'strategic essentialism', a profitable, if provisional, strategy by which an ethnic group deliberately 'forgets' the differences between its members in order to claim its group identity for political purposes. ${ }^{2}$

What I would like to offer here instead is some concrete evidence of the multifaceted state of affairs of the 'black' community in Britain. Indeed, contemporary British fiction may reveal the striking mutual differences between people supposedly belonging to the same community, and may thus offer a valuable cultural space to approach the idiosyncracies of Londonstani's 'apolitical rudeboys' and of 'ex radicals' like Ed Husain in The Islamist. Then, on this basis, I will engage in a brief discussion of multiculturalism in the United Kingdom and its alleged death by cultural relativism and political correctness after the July 72005 London bombings.

Londonstani is the debut novel by Gautam Malkani, a journalist born in Hounslow, West London, in 1976, educated at Cambridge and director of the Creative Business section of the Financial Times. Londonstani is a coming-of-age novel set in Hounslow. ${ }^{3}$ The narrator is Jas, an 18-year old 'Londonstani', a resident of 'Londonistan'. He is trying to fit in with a gang of affluent middle-class teenage

\footnotetext{
${ }^{2}$ Gilroy (1993: pp. 99-103) transcends the binary opposition between racial essentialism and antiessentialism, moving towards an 'anti-anti-essentialism'. See also Rushdie (1991 [1983]: p. 67); Spivak (1996 [1985]: p. 214); and <http://www.english.emory.edu/Bahri/Essentialism. html>.

3 The following details on the plot are taken from a range of written and web interviews with Malkani. Further information on the novel is available on the web, notably at the following links: $<$ http://www.gautammalkani.com/about_londonstani.htm>

$<$ http://www.myspace.com/londonstani>

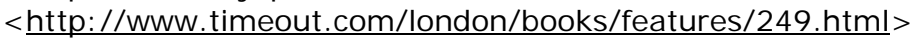


mummy's boys struggling to be tough men and pretending to be more ghettoed than they actually are. The gang leader is the Sikh bodybuilder Harjit, who likes to spell his name with a 'd', Hardjit, to suggest he is hard (Malkani 2006a, p. 116). He makes sure that his Sikh 'bredrens' do not go out with Muslim girls even though he knows nothing about the historical reasons behind that conflict (i.e., the 1947 partition). The second-in-command is Amit, a Hindu more mature than the others; then we have Ravi, one who is a 'sheep', the typical copycat following the others' behaviour and suppressing his own personality. While retaking their A-levels, these wanna-be rudeboys are obsessed with macho and consumerist symbols like facial hair, designer fashion, mobile phones, hip-hop. They cruise Hounslow streets driving German luxury cars belonging to their parents, and make money out of a mobile phone scam involving reprogramming stolen mobiles. Inspired by novels such as S.E. Hinton's The Outsiders (1967) or Rumble Fish (1975), Londonstani offers an insight into the conflict between desis (South-Asians), goras (whites) and coconuts (those black outside, white inside, that is, black people imitating white people). The language used is a striking, challenging and incessant mixture of slang, texting, Panjabi, Hindu, MTV Base slang and gangsta rap.

The first point I would like to make is about racial profiling and identity. As Jas, the narrator, observes at the beginning of the novel: "People're always trying to stick a label on our scene. [...] First we was rudeboys, then we be Indian niggas, then rajamuffins, then raggastanis, Britasians, fuckin Indobrits" (Malkani 2006a, p. 5). In the end the gang is happy to be called 'desi' rudeboys, 'desi' being a 'cooler' and 'stronger' version of Paki. ${ }^{4}$ As Malkani (2006b) himself puts it, "The word 'desi' literally means countrymen [...] It is broader than terms such as Indian, Pakistani, Hindu, Sikh or Muslim, and yet narrower than the term Asian or even South Asian. It acts as a self-determined alternative to [...] the offensive word 'Paki' [...] trying to

\footnotetext{
4 "Desi is a word originally from Sanskrit literally meaning 'from the country' or 'of the country' [...] used colloquially to mean South Asian immigrants and their descendants. It is mainly used by those of South Asian origins themselves, rarely by the majority population, and carries a subtext of inclusiveness and unity [...] its connotations are positive, alluding to the shared values, bonds and experiences of descendants of the entire region. This self-referential colloquialism was created in the United Kingdom during the early 1960s". See <http://en. wikipedia.org/wiki/Desi>
} 
turn it into a positive the way black kids have done with the word 'nigger'”. Even more than goras (whites), the desis despise coconuts, that is, 'poncey', effeminate black guys brown on the outside, white on the inside. Here is a telling description of a coconut: "You could tell from his long hair, grungy clothes, the poncey novel an newspaper on his dashboard and Coldplay album playing in his car that he was a muthafucking coconut. So white he was inside his brown skin, he probably talked like those gorafied desis who read the news on TV". (Malkani 2006a: pp. 20-21). Such aversion towards coconuts is not provoked by the fact that they act like whites: coconuts were despised because they were affected and effeminate, and rather than listening to 'masculine' hip-hop they campaign against environmental pollution and listen to 'poncey' bands such as U2, R.E.M., Radiohead and Coldplay (Malkani 2006a: p. 167). But such process of identification is doomed to change very quickly. In fact, in 2007 one of the most important, if mainstream, black hiphop stars, Jay Z, one of the heroes of our Londonstanis, asked Coldplay singer Chris Martin to collaborate on a track called 'Beach Chair'. This collaboration is evidence that the rudeboy trends and stereotypes are always changing very quickly.

It is now useful to reflect on the title of the book, that is, Londonstani, and the way its meaning has shifted throughout the years. In the beginning, the novel was a piece of academic research, and in the mid-1990s Malkani interviewed a couple of British-Asian kids who referred to themselves as 'Londonstanis', a kind of 'desi', South-Asian, slang for 'Londoner'. Unlike the term 'Londoner', which in Malkani's opinion sounded 'Victorian and cockney', for Malkani 'Londonstani' was a much

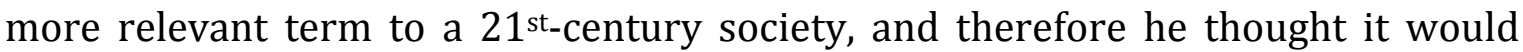
make a perfect title for his book. Back in the 1990s this term conveyed a positive connotation: being a 'Londonstani' meant being a proud Londoner of British Asian origin embodying a positive celebration of London's multiculturalism not dissimilar from what Sammy's often quoted words in Hanif Kureishi's Sammy and Rosie Get Laid suggest: "We love our city and we belong to it. Neither of us are English, we're 
Londoners you see" (Kureishi, 1988: p. 33); that is, a positive, vibrant way of living in the city, generating a strong sense of belonging. 5

Therefore, rather than being stereotypical subservient members of society, or post-7/7 icons of Muslim radical Islamism, the British-Asian apolitical rudeboys in Gautam Malkani's Londonstani reflect a different, religion-free kind of identity ironically embracing the traditionally opposed black hip-hop culture. This novel shows yet another aspect of the multifaceted contemporary black British community as seen in today's 'Londonistan' and a strong anti-essentialist notion of the South-Asian community in London, as these teenage desis are obsessed with macho and consumerist symbols and do not care much about religion: instead, they use racial identity as a proxy for masculine identity and as a way to reaffirm their masculinity.

Since the July 72005 London bombings, the terms 'Londonstani' and 'Londonistan' have taken on more negative connotations. In fact, 'Londonistan' had already been used by French security services in the 1990s to denounce the significant number of radical Muslims and political exiles in London. Also published in 2006 like Londonstani, the book Londonistan by Melanie Phillips is a harsh denunciation of the policy of appeasement that allegedly fostered the growth of radical Islam in Britain. For a wide sector of British public opinion, now the term 'Londonstani' does not convey the idea of a 'positive' multiculturalism, but it is rather a potentially 'dangerous' inhabitant of "Londonistan", the capital of 'Eurabia'.6

\footnotetext{
5 Also the words of Karim Amir, the protagonist of Kureishi's The Buddha of Suburbia (1990) deserve to be quoted at length: "I n bed before I went to sleep I fantasised about London and what I'd do there when the city belonged to me. There was a sound that London had. It was, I'm afraid, people in Hyde Park playing bongos with their hands; there was also the keyboard on the Doors's 'Light My Fire'. There were kids dressed in velvet cloaks who lived free lives; there were thousands of black people everywhere, so I wouldn't feel exposed; there were bookshops with racks of magazines printed without capital letters or the bourgeois disturbance of full stops; there were shops selling all the records you could desire; there were parties where girls and boys you didn't know took you upstairs and fucked you; there were all the drugs you could use. You see, I didn't ask much of life; this was the extent of my longing. But at least my goals were clear and I knew what I wanted. I was twenty. I was ready for anything" (Kureishi 1999 [1990], p. 121).

6 Melanie Phillips was voted the most 'Islamophobic' journalist by the Islamic Human Rights Commission in 2003. The neologism 'Eurabia' refers to a Europe which becomes subsumed by the Arab World. This term was publicized (with a negative connotation) by the writer Bat Ye'or in her
} 
These remarks aptly introduce a brief mention of the other novel, Ed Husain's The Islamist. Unlike Malkani's suburban well-off craving for new objects of desire, this novel is based instead on a real account of a British Muslim who, after becoming an Islamic fundamentalist, rejected political Islam and returned to normal life. The subtitle of the book is very eloquent: 'Why I joined radical Islam in Britain, what I saw inside and why I left'. Therefore, this interesting memoir provides us with a remarkable account of his own experience, updating the situation of radical Islam in Britain which started with the notorious 1988-89 bookburning of Salman Rushdie's The Satanic Verses and Ayatollah Khomeini's fatwa against him. ${ }^{7}$

Ed Husain is the pen name of the British writer Mohammed Mahbub Hussain. He was born in 1975 in London. His father and mother were born in India. When he was sixteen Husain became an Islamic fundamentalist, attending the East London mosque (frequented by many radicals) rather than the moderate Brick Lane mosque, and joining groups such as Hizb ut-Tahrir, the 'Party of Liberation'. A Sunni political party founded in 1953 by Taqiuddin al-Nabhani, an Islamic scholar and judge from Haifa, Hizb ut-Tahrir's goal is to unite all Muslim countries in a unitary Muslim state or caliphate, ruled by sharia (Islamic law) and headed by a caliph, an elected head of state. ${ }^{8}$ Hizb ut-Tahrir has spread to more than 40 countries, is very active in the United Kingdom, and is estimated to have about one million members. In Husain's own words: “They like to call themselves a political party. They are a group of individuals who have members right across the world who are dedicated to overthrowing every single Arab government, every single Muslim government, and setting up an expansionist global state in the Middle East. And, in their words, it's a launch pad for a jihad to go out to other countries. So it's basically creating an Islamist empire." 9 Drawing on Husain's experience as a

book Eurabia: the Euro-Arab Axis (2005). See "Bagehot - In Praise of Multiculturalism", The Economist, J une 14th 2007; and also <http://en.wikipedia.org/wiki/Eurabia>.

7 On December 2, 1988, the first book burning of The Satanic Verses took place in the United Kingdom. 7000 Muslims attended a rally in Bolton during which the book was burnt.

${ }^{8}$ See <http://en. wikipedia.org/wiki/Hizb_ut-Tahrir>

${ }^{9}$ See the transcripts of a CNN video interview (May 2 2007) with Ed Husain:

$<$ http://transcripts.cnn.com/transcripts/0705/04/cnr.02.html> 
recruiter in Hizb ut-Tahrir, The Islamist is a valid socio-historical document that explains the appeal of extremist thought and the way radicals infiltrate Muslim moderate communities. This book is important also because for the first time a former member openly discusses life within radical Islamic organizations. The story of Ed Husain is very useful in revealing how it is possible to have home-grown terrorists willing to kill their fellow citizens in the name of radical Islam.

As we have seen, Londonstani and The Islamist unveil an anti-essentialist condition of the British-Asian community in London involving huge mutual differences between Malkani's 'apolitical rudeboys' and Husain's 'ex-radicals' due to social, cultural and religious background diversities. I would like to conclude by considering briefly the main positions that have emerged lately in the debate on multiculturalism in Britain. After the July 72005 London bomb attack, the debate on multiculturalism has become more passionate than ever. Two positions have emerged in the public opinion: those who are against multiculturalism out of fear of radical Islam and wish to foster social cohesion and a strong sense of belonging to the mother country; and those committed to multiculturalism on the basis of a mutual exchange of cultures and traditions as a privileged path to a more tolerant society. A third position could be that of the protagonists of Londonstani: a peculiar one, as these desis manage to be committed to their own cultural and religious background while at the same time showing ignorance, indifference and mistrust toward politics and the political system. When their teacher asks them: "Have you watched the news? Are you familiar with the debate around multiculturalism? Asylum policy? US foreign policy?'”, Hardjit, the leader of the gang, replies: "'Forget it, man, dis politics shit, it all bout poncey, grey-haired bald people talkin posh $\mathrm{n}$ getting off wid their secretaries, man"' (Malkani 2006a: p. 130). At the same time, though, they feel a strong sense of belonging to their own culture. Despite the fact that he knows virtually nothing about the conflict between India and Pakistan over Kashmir, Hardjit feels strongly against Muslims, and always wears a 'khara', an Indian bracelet round his wrist to show he is a Sikh (Malkani 2006a: p. 9). 
The rise of radical Islam has led British and European writers and commentators such as Gilles Kepel, Trevor Phillips, Melanie Phillips, Yasmin Alibhai-Brown, the Archbishop of York John Sentamu, and many others to declare the death of multiculturalism that, by giving everyone the freedom of encouraging difference, has turned London into Londonistan. ${ }^{10}$ The shock of watching a suicidebomber's video testament delivered in a Yorkshire accent after the bombings probably spelled the end for multiculturalism. Nearly everyone now agrees that multiculturalism has failed. The centre-right wing have always considered it a naive and dangerous idea. Britain's new Prime Minister David Cameron warned against the dangers of 'cultural separatism', and blamed multiculturalism as a failed doctrine threatening national unity and weakening the British collective identity'.11 The same views are shared by contributions such as the above-mentioned book Londonistan by Melanie Phillips, blaming Tony Blair's policy of appeasement towards religious extremism. Similar positions emerge even from the supposedly more progressive centre-left wing. A Commission on Integration and Cohesion, directed by the Labour MP Ruth Kelly, was established after the bombings to advise on segregation and radicalism and recommended that less money be spent on providing civic information in Urdu and Arabic, and more on non-multicultural English lessons. ${ }^{12}$ Even former Prime Minister Gordon Brown has suggested the creation of an annual holiday to recreate a renewed sense of Britishness. Labour and Tory policies on multiculturalism and security seem to be chasing each other. However, despite all its failings and shortcomings, others keep celebrating multiculturalism, claiming it would be wrong to blame it for the rise of radical Islam in Britain, because there are far more pertinent reasons why some young Muslims have become radicalised, such as the British policies overseas, especially the country's involvement in the war in Iraq.

In conclusion, given this complex socio-political scenario, it is difficult to

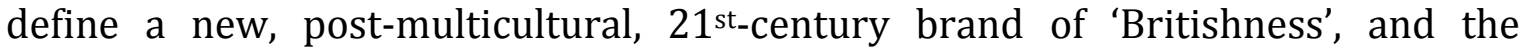

\footnotetext{
${ }^{10}$ See <http://www.timesonline.co.uk/tol/news/uk/article592693.ece>

11 "Bagehot - In Praise of Multiculturalism", The Economist, J une 14th 2007.

12 "Bagehot - In Praise of Multiculturalism", The Economist, J une 14th 2007.
} 
efficacy of steps such as those advocated by the above-mentioned Commission on Integration and Cohesion is debatable. These provisions involve a better cultural preparation for the new arrivals to be assessed via a sort of 'Britishness test', to award citizenship only to selected candidates by helping them understand issues such as the British philosophy of queuing and the importance of avoiding beards and rucksacks. ${ }^{13}$ In Britain and abroad, tolerance and mass xenophobia have recently acquired new connotations. Security has become a top issue on the political agenda, with the revival of restrictive measures such as more 'stop and search' power to the police, and a longer pre-charge detention period for terror suspects. Paul Gilroy (2006, p. 35) has successfully defined this new socio-political scenario as 'securitocracy', Europe's first answer to the growing crisis in race relations.

For younger British-Asians, living in Britain can involve some very different approaches. Radical Muslims - as Ed Husain himself used to be - can react violently against the host society and the fellow 'integrated' members of their community. They fight against consumerism and the decadence of Western society. The protagonists of Londonstani, instead, crave for the very objects despised by radical Muslims. Hyper-materialism is at the core of their credo. They use violence as a way to reaffirm their masculinity, not as a way to rediscover traditional religious doctrines. They do not care about religion, even though the conflict Sikhs vs Muslims becomes useful for them as an excuse to get into yet another fight, never mind their lack of historical awareness of the reasons behind that conflict. Their racial assertiveness is not aimed at religion or politics, but towards the idea of belonging to a 'desi' subculture redeeming via machismo and hyper-materialism

\footnotetext{
13 In an article, writer Mohsin Hamid reports the peculiarity of the questions in this test, whose answers are quite unfamiliar even to British people: "I am reading from pages 24 and 26 of the British Citizenship Test Study Guide. This, for those who are unfamiliar with the foundational text of our common culture, is 'A comprehensive study guide containing official material, study advice and sample questions'. So far, each of my [British] colleagues has on average been able to answer only about one in three questions correctly." Here follows one example:

"Q: If you were visiting a Welsh home during the New Year, what tradition might be observed? A: In Wales, on the stroke of midnight, the back door is opened to release the Old Year. It is then locked to keep the luck in, and at the last stroke, the front door opened to let in the New Year." See Mohsin Hamid, "The British Inquisition", The Independent, February 25, 2007.
} 
their former status of second-class citizens. The protagonists of Londonstani and The Islamist have thus shown that the anti-essentialist notion of the secondgeneration immigrant community in contemporary Britain can be scrutinised through notable examples of contemporary British fiction, examples that help shed light on the current debate on multiculturalism in the United Kingdom. 


\section{WORKS CITED}

- "Bagehot - In Praise of Multiculturalism". The Economist, June 14th 2007.

- AlSayyad, Nezar; Castells, Manuel. "Introduction: Islam and the Changing Identity of Europe". In N. AlSayyad; M. Castells (eds), Muslim Europe or Euro-Islam Politics, Culture and Citizenship in the Age of Globalization, Lanham: Lexington Books, 2002, pp. 1-6.

- Ferguson, Niall. Empire: How Britain Made the Modern World. London: Penguin Books, 2004 (Allen Tate, 2003).

- Gilroy, Paul. "Multiculture in Times of War - An Inaugural Lecture Given at the London School of Economics". Critical Quarterly, vol. 48, no. 4, 2006, pp. 2745.

- Gilroy, Paul. The Black Atlantic: Modernity and Double Consciousness, Cambridge, Mass.: Harvard University Press, 1993.

- Hamid, Mohsin. "The British Inquisition”. The Independent, February 25, 2007.

- Hamid, Mohsin. The Reluctant Fundamentalist. New York: Hartcourt, 2007.

- Husain, Ed. The Islamist - Why I Joined Radical Islam in Britain, What I Saw Inside and Why I Left. London: Penguin Books, 2007.

- Kureishi, Hanif. Sammy and Rosie Get Laid. New York: Penguin Books, 1988.

- Kureishi, Hanif. The Buddha of Suburbia. London: Faber and Faber, 1999 [1990].

- Malkani, Gautam. Londonstani. London: Fourth Estate, 2006a.

- Malkani, Gautam. “Mixing and Matching”. Financial Times, April 22, 2006b.

- Phillips, Melanie. Londonistan - How Britain is Creating a Terror State Within. New York: Encounter Books, 2006.

- Rushdie, Salman. “'Commonwealth Literature' Does Not Exist". In Imaginary Homelands: Essays and Criticism 1981-1991. London: Granta Books, 1991 [1983], pp. 61-70.

- Spivak, Gayatri Chakravorty. "Subaltern studies: Deconstructing historiography". In D. Landry, G. MacLean (eds.), The Spivak Reader: 
Selected Works of Gayatri Chakravorty Spivak. London: Routledge, 1996 [1985], pp. 203-236.

- Ye'or, Bat. Eurabia: the Euro-Arab Axis, Cranbury, NJ: Fairleigh Dickinson University Press, 2005.

\section{WEBLIOGRAPHY}

$<\underline{\text { http://www.english.emory.edu/Bahri/Essentialism.html }>}$

<http://en.wikipedia.org/wiki/Desi>

$<$ http://en.wikipedia.org/wiki/Eurabia>

<http://en.wikipedia.org/wiki/Hizb_ut-Tahrir>

<http://transcripts.cnn.com/transcripts/0705/04/cnr.02.html>

<http://www.gautammalkani.com/about_londonstani.htm>

$<$ http://www.myspace.com/londonstani>

<http://www.timeout.com/london/books/features/249.html>

<http://www.timesonline.co.uk/tol/news/uk/article592693.ece> 